joint registration category, and these cannot be identified separately from published sources. This form of misclassification has probably not changed over the study period in a way that would affect the interpretation of trends. Secondly, the status of the baby at death may be different from that at birth, but this is unlikely to be an issue for most of the deaths occurring within 1 month of birth.

The research highlights the need for lone and unsupported mothers to be given every possible help after the birth of their babies, not just in the neonatal period but on a sustained basis.

We thank Jeremy Schuman, Office for National Statistics, for help in extracting the data on deaths.

Contributors: MW and FD jointly developed the idea for this study and worked on its design. FD carried out the statistical analysis, while MW took responsibility for reviewing the literature. They both then participated in the interpretation of the results and the writing of the paper.

Funding: None

Competing interests: None declared.

1 Bradshaw J. International comparisons of support for lone parents. In: Ford R, Millar J. eds. Private lives and public responses: lone motherhood and future policy in the UK. London: Policy Studies Institute, 1998.

2 Shouls S, Whitehead M, Burström B, Diderichsen F. Trends in the health and socio-economic circumstances of British lone mothers over the last two decades. Popul Trends 1999:95:5-10.(16 March.)

3 Roberts I, Pless B. Social policy as a cause of childhood accidents: the children of lone mothers. BMJ 1995;311:925-8

4 Wadsworth J, Burnell I, Taylor B, Butler N. Family type and accidents in preschool children. J Epidemiol Community Health 1983;37:100-4.

5 Breslow N, Day N. The standard mortality ratio. In: Sen P, ed. Biostatistics: statistics in biomedical public health and environmental science. New York: Elsevier, 1985

6 Macfarlane A, Mugford M. Birth counts: statistics of pregnancy and childbirth. London: HMSO, 1980

7 Leon DA, Vågerö D, Olausson OP. Social class differences in infant mortality in Sweden: a comparison with England and Wales. BMJ 1992;305:687-91.

\title{
Social inequalities and health: ecological study of mortality in Budapest, 1980-3 and 1990-3
}

\author{
P Józan, D P Forster
}

Population and Health Statistics

Division, Hungarian

Central Statistical

Office, Keleti Károly

u $5-7,1525$

Budapest II,

Hungary

P Józan,

chief

11 Ashdale,

Ponteland,

Northumberland

NE20 9DR

D P Forster,

retired consultant

epidemiologist

Correspondence to:

Dr Forster

donforster@the-

forsters.

demon.co.uk

BMJ 1999;318:914-5
Until recently, the health systems in eastern Europe, with minor variations, were all based on the Soviet model. The Soviet principles of health care, formulated in 1918, included provision of care to the poorest sections of the population. ${ }^{1}$ Since 1990 , however, in Hungary a national approach based on health insurance has been introduced. We compared a social disadvantage indicator with standardised mortality ratios for 1980-3 and 1990-3 in Budapest.

\section{Methods and results}

Budapest comprises 22 local administrative districts ranging in population size from 34778 to 174509 . We used three census indicators of disadvantage in 1980 and 1990: the percentage of unskilled workers among the economically active population; the percentage of residents aged $\geqslant 25$ years who had not completed a course at university or college; and, as an indicator of overcrowding, the number of people per 100 rooms in occupied dwellings. We converted each indicator to a $\mathrm{z}$ score (with a mean of 0 and a standard deviation of 1). These $\mathrm{z}$ scores were summed to give a composite social disadvantage indicator. ${ }^{2}$ We sorted the districts in descending order of disadvantage, on the basis of the mean composite indicator for 1980 and 1990, and grouped together the five most disadvantaged districts and the five least disadvantaged.

We defined "amenable" mortality as deaths in the age group 0-64 years that were potentially preventable by direct, timely, and appropriate medical care; we defined "non-amenable" mortality, including ischaemic heart disease, as deaths from all causes in the age group 0-64 years minus amenable mortality. Except for maternal deaths, all mortality data were standardised for age and sex by the indirect method, by using total age, sex, and cause specific rates from 1980-3. Using the confidence interval analysis program, ${ }^{3}$ we calculated the ratio of the standardised mortality ratios (and $95 \%$ confidence intervals) of the most to the least disadvantaged group of districts and, within each group, the ratio of 1990-3 to 1980-3.

The recorded standardised mortality ratios in each diagnostic category and time period were universally lower in the least disadvantaged group of districts than in the most disadvantaged group. The ratios of the standardised mortality ratios of the most to the least disadvantaged groups were all in excess of unity and showed significantly higher mortality for the most disadvantaged group. Moreover, each ratio increased between 1980-3 and 1990-3 (table).

Within the group of most disadvantaged districts, the ratio of standardised mortality ratios in 1990-3 compared with 1980-3 increased significantly in males for all causes (1.05 (95\% confidence interval 1.02 to $1.09)$ ) and non-amenable causes (1.08 (1.04 to 1.12)). In the least disadvantaged group, in both sexes and each diagnostic category, the ratios decreased, with the confidence intervals also lying below unity, except for non-amenable mortality in males $(0.96(0.91$ to 1.01$))$.

\section{Comment}

The increase in inequality of mortality with time among the disadvantaged populations compared with the affluent populations in Budapest, encompassed both amenable and non-amenable categories. These findings are not markedly different from those in Britain during a similar period, although absolute mortality reductions have been smaller in Hungary. ${ }^{4}$ There was no convincing evidence to resolve whether the health effects were the result of absolute or relative differences in deprivation. Between the two periods relative differences between the most and least 
Social disadvantage indicators, standardised mortality ratios (SMRs) for deaths in age group 0-64 years, and ratios for most to least disadvantaged districts in Budapest, 1980-3 and 1990-3

\begin{tabular}{|c|c|c|c|c|c|c|c|c|c|c|c|c|}
\hline \multirow[b]{3}{*}{ Variable } & \multicolumn{6}{|c|}{$1980-3$} & \multicolumn{6}{|c|}{$1990-3$} \\
\hline & \multicolumn{2}{|c|}{$\begin{array}{c}\text { Most } \\
\text { disadvantaged } \\
\text { districts }\end{array}$} & \multicolumn{2}{|c|}{$\begin{array}{c}\text { Least } \\
\text { disadvantaged } \\
\text { districts }\end{array}$} & \multicolumn{2}{|c|}{$\begin{array}{l}\text { Ratio of most to least } \\
\text { disadvantaged }\end{array}$} & \multicolumn{2}{|c|}{$\begin{array}{c}\text { Most } \\
\text { disadvantaged } \\
\text { districts }\end{array}$} & \multicolumn{2}{|c|}{$\begin{array}{c}\text { Least } \\
\text { disadvantaged } \\
\text { districts }\end{array}$} & \multicolumn{2}{|c|}{$\begin{array}{l}\text { Ratio of most to least } \\
\text { disadvantaged }\end{array}$} \\
\hline & $\begin{array}{c}\text { Social } \\
\text { indicator } \\
(1980)\end{array}$ & SMR & $\begin{array}{c}\text { Social } \\
\text { indicator } \\
(1980)\end{array}$ & SMR & $\begin{array}{c}\text { Social } \\
\text { indicator } \\
(1980)\end{array}$ & SMR $(95 \% \mathrm{CI})$ & $\begin{array}{c}\text { Social } \\
\text { indicator } \\
(1990)\end{array}$ & SMR & $\begin{array}{c}\text { Social } \\
\text { indicator } \\
(1990)\end{array}$ & SMR & $\begin{array}{c}\text { Social } \\
\text { indicator } \\
(1990)\end{array}$ & SMR (95\% CI) \\
\hline$\%$ of population unskilled & 8.2 & & 3.5 & & 2.3 & & 6.6 & & 2.5 & & 2.6 & \\
\hline $\begin{array}{l}\% \text { of population without university } \\
\text { or college education }\end{array}$ & 91.8 & & 75.2 & & 1.2 & & 87.2 & & 66.4 & & 1.3 & \\
\hline No of people per 100 rooms & 157.0 & & 127.6 & & 1.2 & & 122.6 & & 101.8 & & 1.2 & \\
\hline \multicolumn{13}{|l|}{ Mortality category } \\
\hline \multicolumn{13}{|l|}{ All causes: } \\
\hline Male & & 114.0 & & 81.5 & & 1.40 (1.34 to 1.46$)$ & & 120.2 & & 74.8 & & 1.61 (1.54 to 1.68$)$ \\
\hline Female & & 108.7 & & 89.2 & & 1.22 (1.16 to 1.28$)$ & & 102.7 & & 74.4 & & 1.38 (1.31 to 1.46$)$ \\
\hline Both sexes & & 111.9 & & 84.6 & & 1.32 (1.28 to 1.37$)$ & & 113.3 & & 74.6 & & 1.52 (1.47 to 1.57$)$ \\
\hline \multicolumn{13}{|l|}{ Amenable causes*: } \\
\hline Both sexes & & 107.4 & & 85.4 & & 1.26 (1.17 to 1.36$)$ & & 94.6 & & 56.7 & & 1.67 (1.52 to 1.83$)$ \\
\hline \multicolumn{13}{|l|}{ Non-amenable causes: } \\
\hline Male & & 115.0 & & 81.3 & & 1.41 (1.35 to 1.48$)$ & & 124.1 & & 77.9 & & 1.59 (1.52 to 1.67$)$ \\
\hline Female & & 109.6 & & 89.2 & & 1.23 (1.16 to 1.30$)$ & & 105.7 & & 78.3 & & 1.35 (1.27 to 1.43$)$ \\
\hline Both sexes & & 112.9 & & 84.4 & & 1.34 (1.29 to 1.39$)$ & & 117.1 & & 78.1 & & 1.50 (1.45 to 1.55$)$ \\
\hline
\end{tabular}

The standard population is Budapest (all districts) in 1980-3 (that is, each standardised mortality ratio for Budapest (total) in 1980-3 is 100).

*Amenable causes=the sum of the following causes: tuberculosis (including late effects) (ICD-9 010-018, 137), ages 5-64; abdominal hernia (ICD-9 550-553), ages 5-64; malignant neoplasms of cervix uteri (ICD-9 180), ages 15-64 (female); hypertensive and cerebrovascular diseases (ICD-9 401-405, 430-438), ages 35-64; chronic rheumatic heart disease (ICD-9 393-398), ages 5-44; maternal deaths (ICD-9 630-676), all ages (female); all respiratory diseases (ICD-9 460-519), ages 1-14; deaths in first year, all causes; asthma (ICD-9 493), ages 15-44; Hodgkin's disease (ICD -9 201), ages 5-64; appendicitis (ICD-9 540-543), ages 5-64; cholelithiasis and cholecystitis (ICD-9 574-575.1), ages 5-64.

disadvantaged groups increased for two indicators and the absolute difference rose only for the proportion who had not completed university or college (from $16.7 \%$ to $20.8 \%$ ). A state controlled approach may be added to the failures of Western systems to reverse the association of poor health with social disadvantage. As the free market economy and health insurance based services replace previous systems in Hungary, and as income distribution becomes more inequitable, urgent research and intervention will be needed to control the social inequality in all aspects of health, as identified by the World Health Organisation's Health for All 2000 initiative. $^{5}$

Contributors: PJ first proposed an interdistrict study in Budapest of the relation between mortality and socioenvironmental variables. He was involved in the definition and selection of the mortality and social disadvantage indices and helped to write the paper. DPF proposed and carried out an analysis based on two time periods. He was involved in the definition of indices and wrote the first draft of the paper.

Funding: None.

Competing interests: None declared.

1 Lisitsyn Y. Health protection in the USSR. Moscow: Progress Publishers, 1972.

2 Carstairs V, Morris R. Deprivation and health in Scotland. Aberdeen: Aberdeen University Press, 1991.

Gardner MJ, Altman DG. Statistics with confidence. London: BMJ, 1989.

4 Boys RJ, Forster DP, Józan P. Mortality from causes amenable and non-amenable to medical care: the experience of Eastern Europe. BMJ 1991;303:879-83

5 World Health Organisation. Targets for health for all. Copenhagen: WHO's Regional Office for Europe, 1985.

(Accepted 19 January 1999)

\section{One hundred years ago \\ The doctor in the pulpit}

It has been said that the medical profession is the priesthood of a scientific age. At the present day the doctor has largely taken the place of the confessor, and in one way or another he preaches as much as most parsons. But he has not yet begun to any extent to "wag his pow" in a pulpit. From the confessional to the pulpit, however, is but a step, and this step, as we learn from the Surrey Mirror, has recently been taken. On Sunday, June 11th, in All Saints' Church, South Merstham, after the ordinary service of evening prayer, Dr. J. E. Usher, by invitation of the rector, preached what was virtually a sermon on the "Gospel of Cleanliness." His homily was full of sensible advice as to the importance of a free use of air, light, and water. Greatly daring, he denounced the ladies who, in their jealous care of their carpets, shut out light and air from their rooms. He had also something to say in condemnation of excessive indulgence in the cup that cheers but not inebriates. If it does not "inebriate," Dr. Usher told his audience it does worse, for it is responsible for part of the increase of insanity which is overtaxing the provision available for the safe custody of lunatics. The ladies were further admonished as to the importance in regard to domestic happiness of "feeding the beast." A bad cook is a causa teterrima belli in the household, an old truth which has quite recently received fresh illustration in the Divorce Court. Altogether Dr. Usher's sermon in South Merstham Parish Church may be taken as an indication of the greater importance which people are coming to attach to public health. It will be interesting to see if the example set by the rector is followed in other parishes. The doctor in the pulpit will do well to stick closely to his text and, like Mark Antony to speak only of that which he knows. (BMJ 1899;i:1549) 